慶應義塾大学学術情報リポジトリ

Keio Associated Repository of Academic resouces

\begin{tabular}{|c|l|}
\hline Title & $\begin{array}{l}\text { Effects of TRH and DN-1417 on high potassium-evoked acetylcholine release from rat basal } \\
\text { forebrain slices determined directly by radioimmunoassay }\end{array}$ \\
\hline Sub Title & \\
\hline Author & $\begin{array}{l}\text { 鈴木, 岳之(Suzuki, Takeshi) } \\
\text { 藤本, 和子(Fujimoto, Kazuko) } \\
\text { 大畑, 尚代(Ohata, Hisayo) } \\
\text { 川島, 紘一郎(Kawashima, Koichiro) }\end{array}$ \\
\hline Publisher & 共立薬科大学 \\
\hline Publication year & 1989 \\
\hline Jtitle & $\begin{array}{l}\text { 共立薬科大学研究年報 (The annual report of the Kyoritsu College of } \\
\text { Pharmacy). No.34 (1989. ),p.89-89 }\end{array}$ \\
\hline JaLC DOI & \\
\hline Abstract & \\
\hline Notes & 抄録 \\
\hline Genre & Technical Report \\
\hline URL & https://koara.lib.keio.ac.jp/xoonips/modules/xoonips/detail.php?koara_id=AN00062898-0000003 \\
\hline 4-0089
\end{tabular}

慶應義塾大学学術情報リポジトリ(KOARA)に掲載されているコンテンツの著作権は、それぞれの著作者、学会または出版社/発行者に帰属し、その権利は著作権法によって 保護されています。引用にあたっては、著作権法を遵守してご利用ください。

The copyrights of content available on the KeiO Associated Repository of Academic resources (KOARA) belong to the respective authors, academic societies, or publishers/issuers, and these rights are protected by the Japanese Copyright Act. When quoting the content, please follow the Japanese copyright act. 


\title{
Effects of TRH and DN-1417 on High Potassium-Evoked Acetylcholine Release from Rat Basal Forebrain Slices Determined Directly by Radioimmunoassay
}

\author{
Takeshi Suzuki, Kazuko Fujimoto, Hisayo Oohata \\ and Koichiro Kawashima
}

鈴木岳之, 藤本和子, 大畑尚代, 川島紘一郎

1. High potassium $(50 \mathrm{mM})$-evoked acetylcholine $(\mathrm{ACh})$ release from rat basal forebrain slices under conditions without an exogenous choline supply was determined using a radioimmunoassay for $\mathrm{ACh}$.

2. A consistent amount of $\mathrm{ACh}$ release was observed at each repetitive stimulation and $\mathrm{ACh}$ content in brain slices was not altered by potassium stimulations. These results indicate the existence of a large intracellular releasable $\mathrm{ACh}$ store, which is independent of new synthesis from exogenous choline.

3. Atropine, even at a concentration of $10^{-6} \mathrm{M}$, did not affect the potassiumevoked $\mathrm{ACh}$ release. Thus, modulation of $\mathrm{ACh}$ release by the muscarinic autoreceptor was not revealed under the conditions employed.

4. Thyrotropin-releasing hormone $\left(\mathrm{TRH}, 10^{-4} \mathrm{M}\right)$ caused a slight and statistically insignificant increase in potassium-evoked $\mathrm{ACh}$ release. DN-1417, a TRH analogue, at a concentration of $10^{-4} \mathrm{M}$ significantly increased potassium-evoked $\mathrm{ACh}$ release. These findings indicate that $\mathrm{DN}-1417$ is able to enhance $\mathrm{ACh}$ output independently of ACh synthesis from exogenous choline.

* 本報告は Gen. Phamacol., 20 (2)，239-242（1989）に発表. 